\title{
Organoleptic Test of Green Mustard Leaf Flour (Brassica juncea) Due to Various Types of Preliminary Treatments
}

\section{Uji Organoleptik Tepung Daun Sawi Hijau (Brassica juncea) Akibat Berbagai Jenis Perlakuan Pendahuluan}

\author{
Dyah Ayu Setyawati ${ }^{1}$, Ida Agustini Saidi ${ }^{2}$ \\ 1,2Program Studi Teknologi Pangan, Fakultas Sains dan Teknologi, Universitas Muhammadiyah Sidoarjo \\ dyahsetya6@gmail.com $^{1}, \underline{\text { idasaidi@yahoo.com }}^{2}$
}

\begin{abstract}
This study aims to determine the effect of preliminary treatment on the quality of organoleptic green mustard leaf flour.This research was conducted in the Laboratory of prodak development of Muhammadiyah University sidoarjo from February to April 2020 using descriptive methods. The experiment was compiled in a Complete Randomized Design with variations of preliminary treatment conducted ie without blanching (TPP), water blanching (PPR), water blanching with soaking salt solution 1\% (PPRG 1), water blanching with soaking salt solution 2\% (PPRG 2), water blansing by immersion of $0.1 \%$ na metabisulfite solution ((PPRN 1), water blanching by immersion of $0.2 \%$ na metabisulfite solution (PPRN 2), steam blanching (PPK) and microwave blanching $(P P M)$. Based on organoleptic tests showed that the preliminary treatment had a noticeable different effect on color and aroma.The best treatment in the manufacture of mustard flour hijua with preliminary treatment is steam blansing that gives a normal value of 0.98 with organoleptic characteristics of color 6.04 (likes-very likes) and organoleptic aromas of 6.12 (likes-very likes).
\end{abstract}

Keywords - Green Mustard Flour; Preliminary Treatment; Blanching

Abstrak. Penelitian ini bertujuan untuk mengetahui pengaruh perlakuan pendahuluan terhadap kualitas Organoleptik tepung daun sawi hijau. Penelitian ini dilakuakn di Laboratorium pengembangan prodak Universitas Muhammadiyah Sidoarjo mulai bulan Februari sampai bulan April 2020. Percobaan disusun dalam Rancangan Acak Lengkap dengan variasi perlakuan pendahuluan yang dilakukan yaitu tanpa blansing (TPP), blansing air $(P P R)$, blansing air dengan perendaman larutan garam 1\% (PPRG 1), blansing air dengan perendaman larutan garam 2\% (PPRG 2), blansing air dengan perendaman larutan na metabisulfit 0,1\% ((PPRN 1), blansing air dengan perendaman larutan na metabisulfit 0,2\% (PPRN 2), blansing uap (PPK) dan blansing microwave (PPM).Berdasarkan uji organoleptik menunjukkan bahwa perlakuan pendahuluan berpengaruh berbeda nyata pada warna dan aroma. Perlakuan terbaik dalam pembuatan tepung sawi hijua dengan perlakuan pendahuluan adalah blansing uap yang memberikan nilai normal 0,98 dengan karakteristik organoleptik warna 6,04 (sukasangat suka) dan organoleptik aroma 6,12 (suka-sangat suka).

Kata Kunci - Tepung sawi hijau; perlakuan pendahuluan; blansing

\section{Pendahuluan}

Sawi hijau (Brassica juncea) merupakan salah satu jenis sayur yang banyak dikonsumsi oleh masyarakat. Dengan semakin meningkatnya kebutuhan akan komoditas sayuran terutama sawi hijau, maka diperlukan upaya untuk meningkatkan kualitas dan kuantitas produk serta pendapatan petani sayuran[1]. Tepung merupakan salah satu bentuk alternatif dari pengolahan hasil pertanian karena dapat memperpanjang umur simpan serta diperkaya akan zat gizi (fortifikasi) sehingga sesuai tuntutan kehidupan modern yang serba praktis[2]. Namun dalam pembuatan tepung memiliki masalah yang dihadapi dalam pembuatannya dimana terjadinya browning[3]. Proses pencoklatan (browning) yang terjadi akan mengurangi kualitas produk serta menurunkan minat pada konsumen [4].

Blansing merupakan pemanasan pendahuluan yang dilakukan terutama untuk menginaktifkan enzim-enzim dalam bahan pangan yang dapat menimbulkan reaksi-reaksi yang merugikan seperti perubahan warna [5]. Metode blansing yang sering digunakan antara lain adalah water blanching atau blansing air dengan cara di rebus, steam blanching atau blansing uap dengan cara di kukus, dan microwave blanching [6].

Sedangkan pada penelitian tepung kentang perlakuan pendahuluan perendaman dan blansing dapat mempertahankan warna tepung [7]. Tepung yang dihasilkan dengan diberi perlakuan pendahuluan perendaman memiliki warna yang lebih baik, serta pemanasan pada suhu tertentu (blanching) dapat menjadi alternatif perlakuan dalam upaya mengurangi penurunan gizi. natrium metabisulfit $\left(\mathrm{Na}_{2} \mathrm{~S}_{2} \mathrm{O}_{5}\right)$ dipilih sebagai bahan perendam karena dapat melindungi bahan dari oksidasi yang menyebabkan rekasi browning [8]. Oleh karena itu dilakukan penelitian untuk mengetahui kualitas dari tepung sawi (Brassica juncea) pada berbagai jenis perlakuan pendahuluan. 


\section{METODE}

Sampel yang digunakan adalah daun sawi hijau yang akan dibuat tepung dengan cara dikeringkan dengan pengering kabinet pada suhu $45^{\circ} \mathrm{C}$, yang sebelumnya dilakukan perlakuan pendahuluan. 8 macam perlakuan pendahuluan yang dalam penelitian ini adalah:

1. Tanpa perlakuan pendahuluan (TPP)

2. Blansing air (PPR)

3. Perendaman larutan garam $1 \%$ dan blansing air (PPRG 1)

4. Perendaman larutan garam $2 \%$ dan blansing air (PPRG 2)

5. Perendaman larutan na metabisulfit $0,1 \%$ dan blansing air (PPRN 1)

6. Perendaman larutan na metabisulfit $0,2 \%$ dan blansing air (PPRN 2)

7. Blansing uap (PPK)

8. Blansing microwave (PPM)

Alat yang digunakan dalam penelitian ini kompor merk Quantum, dandang, baskom, pisau, talenan, pengering kabinet, gelas ukur, grinder, ayakan, timbangan digital. Sedangkan bahan yang digunakan dalam pembuatan tepung sawi hijau adalah daun sawi hijau, garam dan na metabisulfit.

Sawi hijau disortir kemudian dipisahkan antara batang sawi hijau dan daun sawi hijau. Timbang daun sawi hijau sebanyak 150 gram selanjutnya dicuci hingga bersih dengan air mengalir. Blansing daun sawi sesuai dengan perlakuan dan kontrol (tanpa blansing). Blansing air (di rebus) dengan menggunakan $250 \mathrm{ml}$ air dan pada suhu $77^{\circ} \mathrm{C}$ selama 2 menit. Perendaman dengan larutan garam 1\% selama 5 menit kemudian blansing air (di rebus) dengan menggunakan $250 \mathrm{ml}$ air dan pada suhu $77^{\circ} \mathrm{C}$ selama 2 menit. Perendaman dengan larutan garam $2 \%$ selama 5 menit kemudian blansing air (di rebus) dengan menggunakan $250 \mathrm{ml}$ air dan pada suhu $77^{\circ} \mathrm{C}$ selama 2 menit. Perendaman dengan larutan $\mathrm{Na}$ metabisulfit $0,1 \%$ selama 5 menit kemudian blansing air (di rebus) dengan menggunakan $250 \mathrm{ml}$ air dan pada suhu $77^{\circ} \mathrm{C}$ selama 2 menit. Perendaman dengan larutan Na metabisulfit $0,2 \%$ selama 5 menit kemudian blansing air (di rebus) dengan menggunakan $250 \mathrm{ml}$ air dan pada suhu $77^{\circ} \mathrm{C}$ selama 2 menit. microwave blansing (199,5 watt) selama 2 menit. Blansing uap (di kukus) dengan menggunakan $250 \mathrm{ml}$ air dan pada suhu $77^{\circ} \mathrm{C}$ selama 2 menit. Tiriskan menggunakan saringan, atur dalam Loyang, kemudian keringkan dengan menggunakan pengering kabinet pada suhu $45^{\circ} \mathrm{C}$ selama 6 jam. Blender daun sawi yang telah kering selama 4 menit, kemudian ayak dengan menggunakan ayakan 80 mesh.

Penentuan sifat sensori dengan pengujian organoleptik meliputi warna dan aroma dari tepung sawi. Panelis test menggunakan uji hedonik dan hasilnya dinyatakan dalam angka 1 - 7[9]. Dua puluh lima orang panelis diminta untuk menilai sample berdasarkan atas kesukaan dan ketidak sukaan panelis akan sampel tersebut dengan memberikan nilai yang sesuai yang kemudian dilanjutkan dengan uji Friedman[10].

\section{Hasil Dan Pembahasan}

\section{A. Uji Organoleptik Warna}

Hasil uji Friedman menunjukkan bahwa perlakuan pendahuluan berpengaruh sangat terhadap kesukaan panelis akan warna tepung sawi. Rerata nilai kesukaan panelis terhadap warna tepung sawidapat dilihat pada Tabel 1.

Tabel 1. Rerata Kesukaan Panelis Terhadap Warna Tepung Sawi

\begin{tabular}{lclll}
\hline \multicolumn{1}{c}{ Perlakuan } & Rerata & \multicolumn{2}{c}{ Total rank } \\
\hline TPP (Tanpa perlakuan pendahuluan) & 5,56 & 122,5 & $\mathrm{~cd}$ \\
PPR (Blansing air) & 4,76 & 76,5 & $\mathrm{a}$ \\
PPRG1 (Perendaman larutan garam 1\% dan blansing air) & 4,92 & 84,0 & ab \\
PPRG2 (Perendaman larutan garam 2\% dan blansing air) & 5,24 & 107,0 & $\mathrm{bc}$ \\
PPRN1 (Perendaman larutan na metabisulfit 0,1\% dan blansing air) & 5,16 & 102,0 & abc \\
PPRN2 (Perendaman larutan na metabisulfit 0,2\% dan blansing air) & 5,72 & 136,0 & de \\
PPK (Blansing uap) & 6,04 & 153,5 & e \\
PPM (Blansing microwave) & 5,52 & 118,5 & cd \\
\hline
\end{tabular}

Titik kritis

28,49

Keterangan: Angka-angka yang diikuti oleh huruf yang berbeda menunjukkan hasil yang berbeda nyata berdasarkan uji Friedman $(a=0,05)$ 


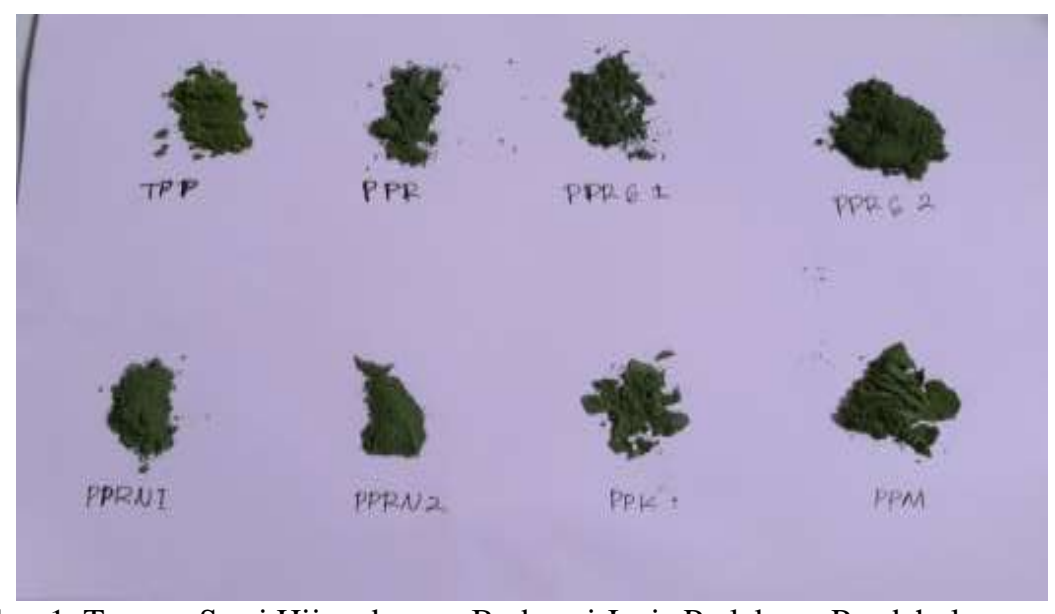

Gambar 1. Tepung Sawi Hijau dengan Berbagai Jenis Perlakuan Pendahuluan

Rerata tingkat kesukaan panelis terhadap warna tepung sawi berkisar antara 4,76 (netra-agak suka) hingga 6,04 (suka-sangat suka). Tingkat kesukaan tertinggi pada perlakuan PPK (blansing uap/kukus) meskipun berbeda tidak nyata dengan perlakuan PPRN 2, namun berbeda nyata dengan perlakuan lainnya. Secara visual panelis lebih menyukai tepung sawi dengan warna hijau cerah.

\section{B. Uji Organoleptik Aroma}

Hasil uji Friedman menunjukkan bahwa perlakuan pendahuluan berpengaruh sangat terhadap kesukaan panelis akan aroma tepung sawi. Rerata nilai kesukaan panelis terhadap aroma tepung sawi dapat dilihat pada Tabel 2.

Tabel 2. Rerata Kesukaan Panelis Terhadap Aroma Tepung Sawi Akibat Perlakuan Pendahuluan

\begin{tabular}{lrrr}
\hline \multicolumn{1}{c}{ Perlakuan } & Rerata & \multicolumn{2}{c}{ Total rank } \\
\hline TPP (Tanpa perlakuan pendahuluan) & 5,92 & 136,5 & $\mathrm{c}$ \\
PPR (Blansing air) & 4,84 & 84,5 & $\mathrm{ab}$ \\
PPRG1 (Perendaman larutan garam 1\% dan blansing air) & 4,16 & 53 & $\mathrm{a}$ \\
PPRG2 (Perendaman larutan garam 2\% dan blansing air) & 4,08 & 55 & $\mathrm{a}$ \\
PPRN1 (Perendaman larutan na metabisulfit 0,1\% dan blansing & 6,2 & 155,5 & $\mathrm{c}$ \\
air) & 6,16 & 155,5 & $\mathrm{c}$ \\
PPRN2 (Perendaman larutan na metabisulfit 0,2\% dan blansing & 6,12 & 153 & $\mathrm{c}$ \\
air) & 5,48 & 107 & $\mathrm{~b}$ \\
PPK (Blansing uap) & & 28,49 \\
PPM (Blansing microwave) & & & \\
\multicolumn{1}{c}{ Titik kritis } & & & \\
\hline
\end{tabular}

Keterangan: Angka-angka yang diikuti oleh huruf yang berbeda menunjukkan hasil yang berbeda nyata berdasarkan uji Friedman $(a=0,05)$

Rerata tingkat kesukaan panelis terhadap aroma tepung sawi berkisar antara 4,08 (netral-agak suka) hingga 6,20 (suka-sangat suka). Tingkat kesukaan tertinggi pada P4 (perendaman natrium metabisulfit $0,1 \%$ dengan perebusan) yaitu 6,20 (suka-sangat suka) meskipun berbeda tidak nyata dengan perlakuan TPP, PPRN 2, dan PPK namun berbeda nyata dengan perlakuan yang lainnya. Aroma langu sawi pada berbagai perlakuan pendahuluan masih dapat terdeteksi oleh beberapa panelis.

\section{Perlakuan terbaik}

Perhitungan mencari perlakuan terbaik tepung daun sawi hijau ditentukan berdasarkan perhitungan nilai efektifitas melalui prosedur pembobotan. Hasil perhitungan perlakuan terbaik adalah tepung daun sawi hijau dengan perlakuan pendahuluan dengan blansing uap yang memberikan nilai normal 0,98 dengan karakteristik organoleptik warna 6,04 (suka-sangat suka) dan organoleptik aroma 6,12 (suka-sangat suka).

Tabel 3. Rerata Perlakuan Terbaik Akibat Perlakuan Pendahuluan 
Procedia of Engineering and Life Science Vol. 1. No. 2 Juni 2021

Seminar Nasional \& Call Paper Fakultas Sains dan Teknologi (SENASAINS 2nd)

Universitas Muhammadiyah Sidoarjo

\begin{tabular}{lcccccccc}
\hline & & & & & & & & \\
& TPP & PPR & PPRG 1 & PPRG 2 & PPRN 1 & PPRN 2 & PPK & PPM \\
\hline Warna & 5,56 & 4,76 & 4,92 & 5,24 & 5,16 & 5,72 & 6,04 & 5,52 \\
Aroma & 5,92 & 4,84 & 4,16 & 4,08 & 6,20 & 6,16 & 6,12 & 5,48 \\
\hline Total & 0,72 & 0,28 & 0,08 & 0,19 & 0,66 & 0,87 & $0,98^{*}$ & 0,63 \\
\hline
\end{tabular}

Keterangan:*perlakuan terbaik

\section{KESIMPULAN}

Perlakuan pendahuluan berpengaruh terhadap kualitas organoleptik dari tepung daun sawi hijau. Hasil perhitungan perlakuan terbaik adalah tepung daun sawi hijau dengan perlakuan pendahuluan dengan blansing uap yang memberikan nilai normal 0,98 dengan karakteristik organoleptik warna 6,04 (suka-sangat suka) dan organoleptik aroma 6,12 (suka-sangat suka).

\section{REFERENSI}

[1] USDA, "National Nutrient Data Base for Standard," Natl. Agriculutural Libr., 2014.

[2] S. W. dan S. Damardjati, D.S., "Sistem Pengembangan Agroindustri Tepung Kasava di Indonesia: Studi kasus di Kabupaten Ponorogo," Penelit. dan Pengemb. Tanam. Pangan, 2000.

[3] K. Sari, T, "Pengaruh Motede Blanching dan Perendaman dalam Kalsium Klorida Untuk Meningkatakan Kualitas French Fries dari Kentang Varietas Tenggo dan Crespo," Skripsi, 2010.

[4] Wahyuningsih, "Pengaruh tirosin, asam askorbat, enzim polifenol, xidase (PPO) terhadap perubahan warna kentang," Gema Teknol. E-jurnal UNDIP, 2010.

[5] J. A. Ambrose, "The Reply," Am. J. Med., vol. 134, no. 3, p. e227, 2021, doi: 10.1016/j.amjmed.2020.10.039.

[6] Z. Effendi, F. E. D. Surawan, and Y. Sulastri, "Sifat Fisik Mie Basah Berbahan Dasar Tepung Komposit Kentang dan Tapioka," Agroindustri, vol. 6, no. 2, pp. 57-64, 2016, [Online]. Available: http://ir.obihiro.ac.jp/dspace/handle/10322/3933.

[7] S. S. H. R. Shri K. Sharma, Steven J. Mulvaney, Food process engineering: theory and laboratory experiments. New York: New York: Wiley-Interscience, 2000.

[8] A. Slamet, "Pengaruh Perlakuan Pendahuluan pada Pembuatan Tepung Ganyong (Canna edulis) Terhadap Sifat Fisik dan Amilografi Tepung yang dihasilkan," Agrointek, vol. 4, no. 2, pp. 100-103, 2012, [Online]. Available: http://kompetensi.trunojoyo.ac.id/agrointek/article/view/1361/1169.

[9] Setyaningsih dkk, "Analisis Sensori untuk Industri Pangan dan Agro," IPB Press Bogor, 2010.

[10] De garmo dkk, "Engineering economi," 7th Ed. Mc Millan Publ, 1984. 